\title{
Designing Teaching Portfolios Based on a Formal Model of the Scholarship of Teaching
}

\author{
Carolin Kreber \\ University of Alberta, Edmonton
}

Many universities now encourage, and some even require, faculty to submit a teaching portfolio as part of their tenure application package. How to evaluate these portfolios, bowever, remains an unresolved issue, particularly if the task is to make a judgment about whether what is demonstrated in the portfolio reflects engagement in the scholarship of teaching. The thesis of this chapter is that judgments regarding the validity and truthfulness of a teaching portfolio can be made by assessing the extent to which the author has attended to an agreed-upon process of knozeledge construction and validation in teaching. A model of the scholarship of teaching is proposed that could guide the design and evaluation of portfolios and an illustration of the process is given.

\section{INTRODUCTION}

The 1990s have witnessed a strong interest in the scholarship of teach1 ing, a concept first introduced by Boyer (1990) and Rice (1991, 1992) with the purpose of broadening the widely spread but narrowly conceived interpretation of scholarship as discovery research, but since then further developed by those who advocate not only greater recognition of college and university teaching but also its advancement (for example, Edgerton, Hutchings, \& Quinlan, 1991; Glassick, Huber, \& Maeroff, 1997; Kreber, in press; Kreber \& Cranton, in press; Menges \& Weimer, 1996; Paulsen \& Feldman, 1995; Richlin, 1993; Shulman, 1998). Whether the interest lies primarily in the recognition of teaching, or its advancement, or both, the observation that teaching is largely a private activity happening behind 
closed classrooms doors while research is public, and, therefore, open to peer review, has been made by all proponents of the scholarship of teaching. This fundamental difference between the activities of research and teaching resulted in the formulation of the problem of how teaching could become more public and thereby open to a process of peer review, similar to that used for research.

In response to this question, many universities now encourage, and some even require, faculty to submit a teaching portfolio as part of their tenure application package. A teaching portfolio is essentially an instructor's self-portrait of his or her approaches and accomplishments in teaching; this means that the instructor chooses how to present him- or herself, just as a researcher chooses how to present a study in a scholarly article. However, a teaching portfolio is not just a snapshot illustration and analysis of an instructor's teaching but rather a series of snapshots taken over time to demonstrate his or her evolution as a teacher.

The objective of this essay is threefold: first, to review literature on the purpose and content of the teaching portfolio and address the still unresolved issue of assessment. Second, to introduce a formal model of the scholarship of teaching (Kreber, 1999; Kreber \& Cranton, in press). As part of this second objective, an attempt will be made to define the apparently rather elusive concept of the scholarship of teaching in clear and accessible terms. In doing so, the author will draw on the results of a recent Delphi study conducted with a panel of international experts in this field (Kreber, in press). The third goal is to demonstrate how the proposed model could guide the design and evaluation of teaching portfolios, particularly if the purpose of the assessment is to identify whether what is reported in the portfolio demonstrates a faculty member's engagement in the scholarship of teaching. The model of the scholarship of teaching described in this chapter is considered formal as it is derived through deductive analysis of Jack Mezirow's (1991) theory of transformative learning, a notion developed in the adult education literature and informed by both critical social theory (Habermas, 1971, 1984) and constructivist psychology (Kelly, 1955). It also appears to be consistent, overall, with the results of the recent Delphi survey (Kreber, in press).

\section{The Teaching Portfolio}

The idea of the teaching portfolio originated in Canada in the early 1970s (Knapper, McFarlane, \& Scanlon, 1972) and later resulted in a publication sponsored by the Canadian Association of University Teachers 
(CAUT) titled "The teaching dossier: A guide to its preparation and use" (Shore et al., 1980, 1986). Teaching portfolios have both formative and summative purposes. By keeping a record of their teaching over time, faculty have the opportunity to reflect on the data they collect, make changes as a result, and compare the data and evidence gathered after the change has been implemented to those of the previous year. As a result of this cyclical process, they demonstrate responsibility for their professional development in teaching. More problematic is the use of teaching portfolios for summative purposes. In case a teaching portfolio is required as part of the tenure application, for example, an evaluation committee will be charged with the task of making a decision about the faculty member's teaching prowess. The various documents and sources compiled in the teaching portfolio, among them a philosophy statement, outlines of courses taught, unsolicited comments from students, written feedback from colleagues, examples of course work completed by students, summary of teaching evaluation from students, and so forth, certainly provide a broader and perhaps more objective picture of teaching than student ratings of instruction alone. Furthermore, teaching portfolios allow faculty to gain greater responsibility for (and control over) the evaluation of their teaching (Shore et al., 1986). Notwithstanding these significant benefits, some unresolved issues remain. To date, the following problems have been addressed insufficiently:

- How can teaching portfolios be assessed without a definite set of criteria that guide such an evaluation (Knapper, 1995)?

- How can teaching portfolios be assessed without the assessors being trained in such evaluation?

- Who is in a position to decide what is a good teaching philosophy statement - the basis of one's teaching - and what is not?

With respect to the third problem consider a well-articulated statement that reflects a general philosophy that is not shared by the majority of committee members. To what extent does it make sense to argue that one philosophy is better than another? To what extent does a philosophy statement fall under the auspices of academic freedom? Put differently, to what extent should it be accepted (as scholarly) without questioning the validity and truthfulness of the statement-or in other words-the process by which results (beliefs about teaching) have been achieved?

The thesis of this essay is that judgments regarding the validity and truthfulness of a teaching philosophy statement-and, for that matter, 
all sections of a teaching portfolio-can be made by assessing the extent to which the author of the statement has attended to an agreed upon process of knowledge construction and validation in teaching. A formal model of the scholarship of teaching that purports to explain these processes will be introduced next.

\section{A Formal Model of the Scholarship of Teaching}

The scholarship of teaching means different things to different people; yet a recent Delphi study (Kreber, in press) showed that there is consensus among those studying the subject that not every person that teaches practices the scholarship of teaching, but that the scholarship of teaching requires sound knowledge of how students learn. Faculty acquire this knowledge as they explore the relationships between teaching and learning.

Menges and Weimer (1996) demonstrated how formal or researchbased knowledge on teaching and learning can inform our teaching practice. Faculty reading about relevant educational research enhance their knowledge of how students learn. At the same time, the authors encourage the development and dissemination of the wisdom of practice; that is, the insights faculty gain from their personal teaching practices and their own informal or formal study of teaching and learning. Recently, Weimer (in press) suggests that the "wisdom of practice" itself needs to be improved so as to rely not only on experiential knowledge but to be informed by, and perhaps extend, what we have come to understand about teaching and learning. According to these authors, it is both existing formal or research-based knowledge, as well as faculty's experience-based knowledge of teaching and learning, which contribute to the scholarship of teaching. Participants in the Delphi study agreed on a series of statements that define the scholarship of teaching. The five that seem most relevant to the argument presented in this chapter are reported here (for a more comprehensive report and discussion of this study please see Kreber, in press):

1) Those that practice the scholarship of teaching carefully design ways to examine, interpret, and share learning about teaching. Thereby they contribute to the scholarly community of their discipline.

2) The scholarship of teaching entails a public account of some or all of the following aspects of teaching: vision, design, interaction, outcomes, and analysis, in a manner that can be peer reviewed and used by members of one's community 
3) The conduct of research on teaching and learning (less formal and formal) contributes to the advancement of pedagogical content knowledge, and presents forms of the scholarship of discovery that overlap with, and are part of, the scholarship of teaching.

4) The scholarship of teaching is an activity that, in the context of promoting student learning, meets each of the following criteria:

- it requires high levels of discipline-related expertise

- it breaks new ground and is innovative

- can be replicated and elaborated

- can be documented

- can be peer reviewed

- has significance or impact

5) A person practicing the scholarship of teaching is aware of, experiences, and can express an underpinning conceptual framework for their teaching; a framework that is strongly related to students learning outcomes.

Kreber and Cranton (in press) introduced a model of the scholarship of teaching that is intended to both explain and guide the development of the scholarship of teaching. Furthermore, the model conceives of scholarship not only in terms of outcomes-that is the knowledge faculty have gained-but gives equal emphasis to the process of acquiring this knowledge. Two basic assumptions underlying the model are:

1) Faculty learn about teaching through reflection on both researchbased and experience-based knowledge about teaching; thereby they develop pedagogical knowledge in a broad sense as well as pedagog. ical content knowledge.

2) Faculty can demonstrate their learning in the form of a teaching portfolio.

\section{Reflection on Teaching}

Following George Kelly's (1955) notion of "constructive alternativism," Mezirow (1991) argues that people construct their own realities on the basis of their interpretation of events and that these interpretations, in 
turn, function as perceptual filters in how they go about understanding their environment. These perceptual filters or meaning perspectives determine the expectations they have for the outcome of events. Sometimes the expected outcome does not take place; in this case, the individual has the choice to reflect on the experience and to revise the original expectation, and his or her perspective. With respect to faculty learning about teaching, an example might be a faculty member who expects students to abuse an opportunity to self-evaluate their learning but finds that the majority of students evaluate themselves quite accurately and some even lower than he or she would have done. The faculty member may revise his or her assumption that incorporating self-evaluation in college classes leads to grade inflation.

Reflection can occur on three different levels. Mezirow (1991) distinguishes content, process, and premise reflection. An individual engaging in content reflection describes the problem and asks, "What do I know should be done in this situation?" A person engaging in process reflection asks, "How do I know that?" This second form of reflection addresses the process of problem solving. Finally, a person engaging in premise reflection asks, "Why is it important that I address this problem in the first place?" Mezirow (1991), who bases his theory of transformative learning also largely on Jürgen Habermas' $(1971,1984)$ work of a critique of ideology, argues that only premise reflection is critical reflection and can lead to emancipatory learning. Emancipatory learning is the kind of learning whereby individuals come to question the origins and validity of the presuppositions that guide their beliefs and actions (Cranton, 1994, 1996; Mezirow, 1991). Content and process reflection are not insignificant, however, and can lead to important instrumental learning (identifying cause-effect relationships through the empirical-analytical method) and communicative learning (achieving deeper understanding of the meaning of experience through the hermeneutic cycle).

Following this theory, Kreber and Cranton (in press) and Kreber (1999) argued that faculty develop scholarship in teaching as they engage in content, process, and premise reflection on research-based and experience-based knowledge about teaching. The scholarship of teaching, therefore, comes about as a result of various combinations of instrumental, communicative, and emancipatory learning processes, resulting in knowledge about instruction, pedagogy (including pedagogical content knowledge), and the larger curriculum. Following this model, faculty can provide evidence of their scholarship of teaching by demonstrating that they have reflected on research-based and experience-based knowledge of 
teaching on any of the three levels (content, process, and premise), and acted on the results of their reflection. As faculty's learning and knowing about teaching can be demonstrated, it follows that, given appropriate criteria, it can be assessed through a process of peer review (Kreber, 1998). How this model can facilitate the design and evaluation of teaching portfolios will be discussed below.

\section{Using the Model to Design Teaching Portfolios}

The notions of content, process, and premise reflection provide meaningful guidance for the design and evaluation of teaching portfolios. When faculty engage in the "what," "how," and "why" questions posed by the model of the scholarship of teaching, they develop a self-portrait of their approaches and achievements in teaching. Content reflection asks "What do I presently do?" and "What have I accomplished?" Process reflection asks, "How do I know that what I do is effective?" and premise reflection asks, "Why does it matter that I address this problem in the first place?" When individuals engage in premise reflection they question the presupposition that the problem is in fact relevant.

One important part of the teaching portfolio is the teaching philosophy statement. Interestingly, it is this section that most faculty have considerable difficulty expressing (Richlin, 1995); and yet it is this philosophy that is the basis for how they approach their teaching. Identifying the reasons behind the approaches they take is not something faculty engage in routinely. Examples of such statements exist in the teaching and learning literature (for example, Brookfield, 1990, 1995; Cranton, 1992, 1996; Goodyear \& Allchin, 1998); however, few faculty are familiar with these texts, and many feel somewhat at a loss when it comes to articulating their beliefs about teaching.

Generally speaking, philosophies provide a rationale for educational practice (Lawson, 1991; Ozmon \& Graver, 1990). Goodyear and Allchin (1998) suggest that "articulating an individual teaching philosophy provides the foundation by which to clarify goals, to guide behavior, to seed scholarly dialogue on teaching, and to organize evaluation" (p. 103). Weimer (1987) defines a theory of practice as "the collection of assumptions and beliefs that form the bedrock beneath the more visible activities of teaching. It's the rationale behind what we do in the classroom" (p. 1). Similarly, Brookfield (1990) encourages us to "develop a philosophy of practice, a critical rationale for why you are doing what you are doing” (p. 195). Apps (1973) suggests that educators should undergo a 
systematic analysis of the philosophy they are working from. Beliefs should be identified in terms of at least five categories: the overall purpose of education, beliefs about the educator, beliefs about the learner, beliefs about the subject area, and those related to the learning process. A study exploring the teaching philosophies espoused by faculty from different disciplines at a large research university in Canada (Scott, Chovanec, \& Young, 1994) found that faculty view their teaching in terms of six dimensions. These show considerable resemblance to Apps' categories. Faculty hold assumptions regarding:

1) the purpose of university teaching and learning

2) the role of the teacher

3) the role of the learner

4) the methods and strategies used

5) evaluation and assessment

6) constraints

In order to show how the notions of content, process, and premise reflection on formal educational research and personal teaching experience can be helpful to faculty in articulating their beliefs within these six dimensions, this section concludes with an example drawn from the author's own teaching philosophy statement. Within each dimension, content reflection encourages individuals to make their beliefs explicit. This is where most teaching philosophy statements end. The thesis of this essay is that articulating one's beliefs, while necessary, is not sufficient if the goal is to demonstrate one's engagement in the scholarship of teaching. To reiterate, the scholarship of teaching requires demonstration of knowledge about teaching, the application of this knowledge, as well as its advancement through pedagogical content knowledge (Paulsen, in press), in a way that can be peer reviewed. It is process reflection that leads faculty to provide evidence for their beliefs. Such evidence is grounded in the existing educational literature and personal teaching experience. Finally, when individuals engage in premise reflection, they both gain and show awareness of why it is meaningful to attend to the problem in the first place.

For reasons of limited space and the purpose of illustration, the example that follows will focus on four dimensions of the teaching philosophy statement: 1) the purpose of higher education, 2) the role of stu- 
dents, 3) the strategies used, 4) and the assessment of learning. It should be noted that the philosophy statement, typically, is considered a onepage articulation of one's beliefs. As such, it is conceived of more as an introduction to the portfolio rather than the essence of the portfolio. The argument here is that the philosophy statement determines and guides everything we do in teaching. As such, all aspects of the teaching portfolio can be-and perhaps should be-integrated within this statement. A good teaching philosophy statement explains why certain approaches were taken and makes reference to supporting material in the appendix section. The philosophy statement is therefore not an introduction to but is the teaching portfolio. To be complete, it should address all six dimensions discussed earlier.

\section{Example of a Teaching Philosophy Statement Based on Content, Process, and Premise Reflection on RESEARCH-BASEd AND EXPERIENCE-BASEd KNOWLEdGe \\ The Purpose of Higher Education \\ (IN MY FIELD OF STUDY - ADULT LEARNING)}

\section{Content Reflection}

I see the purpose of university education as helping learners recognize the links between research in the field and their practice and how both inform each other. I think that universities are places where people need to learn to take responsibility for their learning, to argue reasonably, and to respect different viewpoints, cultures, and ways of living. In short, I think that universities are places where people grow professionally, intellectually, and personally. I also think that universities are places that can stimulate a love for learning.

\section{Process Reflection}

Research on university student development in university (for example Astin, 1993; Baxtor-Magolda, 1992, King \& Kitchener, 1994; Perry, 1970; Pascarella \& Terenzini, 1991) indicates that higher education has positive effects on students on all three levels. A couple of years ago when facilitating a discussion group among colleagues on the goals of higher education and the development of critical thinking skills in students, I was stunned by how differently the concept of critical thinking and 
development is construed (for example, as problem-solving and advancement in the discipline on the one hand versus as development as a person and reflective citizen, on the other). Participating in electronic discussion forums such as the STLHE or POD listservs further contributed to my thinking in this area.

My experience as a university student and junior faculty member further supports this assumption. It is not the exception when students comment after a course that assumptions were challenged and they want to make changes to their practice, that they are motivated to learn more about the subject, or that they want to become an academic (see appendix for comments from students).

\section{Premise Reflection}

Brookfield in his book The Skillful Teacher (1990) offers four reasons for why it is important to be clear on one's goals and purposes. Personally, I find that it provides structure and consistency to my teaching. Sometimes students do not want to be challenged - they are tired after a day of work, and their major reason to come to class that night is to get credit for the course. They then are quick to challenge the educator who tries to foster critical thinking, collaborative work, and self-direction. Without a rationale that justifies my approach, I think I would have to give in to their felt needs without any meaningful discussion.

\section{The Role of Students}

\section{Content Reflection}

I see the student's role as one of co-learner, co-planner, and to some extent expert (many of my students have many more years of teaching experience than I do, and some hold professional degrees). I think that students' reasons for participation vary considerably: Some do it because they need the degree, some do it because they want to learn about the subject in order to either enhance their practice or embark on an academic career, and others do it primarily to interact with others and be a little challenged (Houle, 1961). I realize that my expectations of them (with respect to the nature of the assignments) vary with their reasons for participation - this is a critical issue that I have not quite resolved for my- 
self. Not surprisingly perhaps, I prefer working with those that are academically inclined. Across all students, however, I expect them to come to class well-prepared, be willing to engage in class discussions and activities, to assume some responsibility for their learning in the course, justify their point of view, listen to and reflect on other people's points of view, and demonstrate respect toward all other members of the group.

\section{Process Reflection}

How do I know that these expectations are reasonable? I have noticed that most of the students I work with have a wealth of relevant professional or life experience that can contribute in very positive ways to the course. I also observe that once learners have identified their goals and had input into how they can achieve those, they are more highly motivated to succeed. I realize that once students have noticed how much more they get of out of the class if they prepare for it, they also see the value of it. On a theoretical level, some of the literature on self-directed learning suggests that adequate degrees of learner control enhance motivation to learn (for example Candy, 1991; Garrison, 1997). The literature on inclusive classrooms raises our awareness that all voices should be respected (Brownlie \& Feniak, 1998).

\section{Premise Reflection}

Being aware of the roles that I expect of the students allows me to articulate these expectations clearly at the beginning of the course. It seems to me that I owe course participants this information and disclosure. It is then up to them to decide whether they want to stay in the course or leave. If they stay, I take this as their consent/agreement with what I proposed.

\section{The Teaching Strategies I Use}

\section{Content Reflection}

I use a combination of lecture, discussion, and many forms of group work. I often have different groups review a text that was assigned for the particular class and ask them to identify what, in their view, were the key points of the reading. Then I have them articulate how these points relate 
to, or inform, their practice. I also ask them to reflect on what is not yet known about the topic, and what they would suggest as an important step in future research. After 30-45 minutes of group work, I have each group report back to the other members of the class. In case I think that certain important issues have been neglected, I raise them. I also provide further information drawn from my own reading or research. With the goal of making students aware of the assumptions or knowledge they hold, I also use role play, debates, short case studies, and critical incidents. Research on collaborative learning suggests such approaches have positive effects on students learning (e.g., Matthews, 1996).

\section{Process Reflection}

My experience with following a very interactive approach in my classes and to varying the instructional methods has been very positive. Many students comment that a particular activity helped them to better see the link between theory and practice, or the difference between certain theories, or some simply comment after class that they can't believe that three hours have gone by and they had so much fun. Surely, having fun in class isn't everything but I think it's good when it happens. On a more theoretical level, the educational literature encourages teachers to use a variety of instructional methods in order to sustain students' attention, to not teach exclusively to one particular type of learner, and to make sure that the methods chosen are appropriate in relation to the learning task defined by the learning objective (Cranton, 1992; Fuhrman \& Grasha, 1983; Svinicki \& Dixon, 1987). Higher-order learning, in particular, tends to be fostered in a learning environment characterized by dialogue, collaboration, mutual respect, and constructive criticism (Donald, 1997).

\section{Premise Reflection}

I think knowledge about teaching strategies and when to use them is critical because as a professional educator I want to be able to justify my practice. For example, it would be very hard for me to justify the exclusive use of the lecture method in my course with a group of 16 students of diverse cultural backgrounds, prior knowledge, learning styles, and personality types, when the majority of learning objectives are aimed at students' ability to explain and discuss critical issues. 


\section{How I Assess Learning}

\section{Content Reflection}

At the undergraduate level, my intent is to have learners not only absorb primarily instrumental knowledge (e.g., how to design instructional interventions; how to conduct program reviews and assessments of learning) but to become critically reflective professionals. With this purpose in mind, I have them keep a reflective learning journal on their experiences as learners and educators and analyze it, just like any other piece of qualitative data, for underlying themes and assumptions. I also ask them to identify and discuss the relationships they see between their educational philosophy, values, learning style, teaching style, and psychological type; to develop not only technically sound but meaningful learning objectives; to select appropriate strategies; and to provide a rationale for their choice. Finally, I ask them to articulate their theory of practice. As simplistic as this may sound, many students have tremendous difficulty identifying their assumptions and often uncritically assimilate information. Furthermore, these assignments require students to synthesize the material covered in class. Students do not earn grades for quantity but quality; arguments need to be backed up by sound reasons, and evidence for critical engagement with the material.

At the graduate level, reflection on one's practice is just as important, but I also evaluate students' research ability and knowledge of the field. Weekly insight cards (one-page [reflective] annotations based on the readings) ensure that learners have actively engaged with the material. I do not ask them to summarize the text but to identify just one or two issues they found interesting and articulate why. The second assignment is to identify a research question, conduct a literature search, and write an annotated bibliography on the selected readings. Here I expect to see good understanding of content as well as critical engagement. The third assignment is a discussion paper based on the books and articles reviewed for the annotated bibliography. Here I expect an ability to synthesize research material, recognize strengths and weaknesses, and draw plausible conclusions. In both undergraduate and graduate courses I encourage students to submit their work any time for formative evaluation. On an 
informal level, I evaluate learning by asking questions in class. Listening to students' group presentations and observing individual students during activities, also allows for a fairly accurate assessment of their learning. Many students also offer unsolicited comments.

\section{Process Reflection}

Students have conducted excellent work this way, as demonstrated by the high quality of their assignments at both the graduate and undergraduate levels. Furthermore, the educational literature (for example Bloom \& Krathwohl, 1956) suggests that higher-order learning is encouraged when students have to analyze, synthesize, and evaluate information and process it on a deep level (Biggs, 1987; Entwistle \& Ramsden, 1983). It seems to me also that students' self-direction and motivation is enhanced when there is some choice regarding assignments. In the graduate course, students choose the topic for their annotated bibliography and term paper. In the undergraduate course, students have a choice with respect to at least one of the assignments.

In one instance, I conducted a classroom research project on students' conceptualization of course content before and after the class. The study was later published (see Teaching in Higher Education).

\section{Premise Reflection}

I think it is important that I evaluate the learning of students in my courses so that they receive feedback on their learning process. With some students, the feedback I provide is more supportive; with others it is more challenging-it all depends on the individual student. At any rate, I think it is important to help students self-regulate their learning, including monitoring the objectives they set, the learning strategies they choose, and the beliefs they hold about themselves as learners. I also think it is important that students receive feedback on whether their conceptualization of course content is appropriate.

\section{Evaluating the Teaching Portfolio}

So how would or could such a statement be peer reviewed? Whether or not the various assumptions and beliefs articulated in the philosophy 
statement are actually practiced can be demonstrated in the appendix section of the teaching portfolio. Course outlines, results from formative and summative evaluations of teaching, examples of classroom research projects, criteria used for assessing student learning, excerpts from the literature on learning that struck a chord, own published work on teaching and learning, to mention just a few examples, provide evidence regarding the truthfulness of the statement. Members of faculty evaluation committees who understand the notions of content, process, and premise reflection on research-based and experience-based knowledge could make a judgment of the extent to which a philosophy statement is plausible by looking for evidence of the faculty member's engagement in the three forms of reflection, his or her awareness of educational research relevant to teaching and learning, and the degree to which he or she has made an effort to learn from personal teaching experience. In making a decision regarding the validity of a teaching philosophy statement, the defining criterion is therefore not whether or not other members of the academy espouse the same beliefs, but whether what is suggested in the statement seems plausible if evaluated against the proposed model of the scholarship of teaching.

As part of their model, Kreber and Cranton (in press) provide a list of indicators of engagement in the scholarship of teaching which could guide such peer review. Indicators are seen as the concrete action faculty take from which active engagement in the scholarship of teaching can be inferred. Some suggestions for such indicators follow (for a more comprehensive list sees Kreber \& Cranton, in press):

1) asking for peer review of course outline

2) collecting data on students' perceptions of methods and materials

3) experimenting with alternative teaching approaches and checking out results

4) writing critiques on "how-to" books

5) administering learning styles or other inventories to students

6) writing an article on how to facilitate learning in the discipline

7) gathering feedback from students on their learning the concepts of the discipline

8) reading articles or books on learning theory

9) conducting an action research project on student learning 
10) comparing classroom experience to formal research results on student learning

11) participating in philosophical discussions on student learning on, for example, a listserv or with colleagues

12) reading books on the goals of higher education and comparing goals to those underlying the programs offered in the department

Clearly, other indicators are possible, and the development of further indicators by those who practice the scholarship of teaching is both necessary and encouraged. Note that these indicators are not meant to be used as a checklist in a sense that if all indicators are checked off then we have an example of the scholarship of teaching. It seems more meaningful to take the indicators as what they are, a list of suggestions, and become comfortable with the idea that the scholarship of teaching can probably be demonstrated in many different ways (see for example, Theall \& Centra, in press). At the same time, however, not every teaching portfolio will be an example of the scholarship of teaching. The Delphi panel in the above mentioned study also raised the question whether and how excellence in teaching versus the scholarship of teaching could be valued. A discussion of this question can be found in Kreber (in press). The focus in this essay is the teaching portfolio as a way of demonstrating the scholarship of teaching, not excellence in teaching. Clearly, teaching portfolios are very appropriate for demonstrating teaching excellence also.

The most difficult problem to be tackled in the process of peer review is to make the critical discrimination between excellent teaching and the scholarship of teaching. Addressing the following three questions will be paramount: 1) Did the individual engage in content, process, and premise reflection on experience-based and research-based knowledge about teaching and learning? 2) In doing so, did the individual contribute to the development of pedagogical content knowledge? 3) Was this pedagogical content knowledge shared with other members of one's discipline?

The degree to which this was done, I would suspect, is an indication to the degree to which the person demonstrates the scholarship of teaching. To complicate matters further, it would follow that faculty can demonstrate the scholarship of teaching not only in different ways but most likely also to varying degrees.

If the model of the scholarship of teaching were accepted by the larger academic community, it could also be conceptualized as a set of agreed-upon norms. When members of a faculty evaluation committee 
engage in dialogue around the plausibility of a teaching philosophy based upon these norms, they construct communicative knowledge (Cranton, 1994; Habermas, 1984; Kreber \& Cranton, in press; Mezirow, 1991), where the rightness or plausibility of an argument is determined by consensus within a community of peers.

\section{SUMMARY}

The purpose of this essay was to demonstrate that a formal model of the scholarship of teaching could be effectively used for the design and evaluation of teaching portfolios. As the teaching philosophy section of the teaching portfolio was shown to be difficult to write for many faculty, the chapter offered an example to illustrate how the notions of content, process, and premise reflection on research-based and experience-based knowledge can guide the articulation of one's teaching philosophy. At the same time, suggested that the format provides a way of assessing the extent to which the teaching portfolio demonstrates engagement in the scholarship of teaching, a process inadequately addressed to date.

\section{REFERENCES}

Apps, J. W. (1973). Towards a working philosophy for adult education. (ERIC Document Reproduction Service No. ED 078 229).

Astin, A. W. (1993). What matters in college? Four critical years revisited. San Francisco, CA: Jossey-Bass.

Baxter Magolda, M. (1992). Knowing and reasoning in college: Gender-related patterns in students' intellectual development. San Francisco, CA: Jossey-Bass.

Biggs, J. R. (1987). Students' approaches to learning and studying. Melbourne, Australia: ACER Press.

Bloom, B. S., \& Krathwohl, D. R. (1956). Taxonomy of educational objectives: The classification of educational goals. New York, NY: Longmans.

Boyer, E. L. (1990). Scholarship reconsidered: Priorities of the professoriate. Princeton, NJ: Carnegie Foundation for the Advancement of Teaching.

Brookfield, S. (1990). The skillful teacher. San Francisco, CA: Jossey-Bass.

Brookfield, S. (1995). Becoming a critically reflective teacher. San Francisco, CA: Jossey-Bass.

Brownlie, F., \& Feniak, C. (1998). Student diversity: Addressing the needs of all learners in inclusive classrooms. Markham, Canada: Pembroke. 
Candy, P. (1991). Self-direction for lifelong learning. San Francisco, CA: Jossey-Bass.

Cranton, P. (1992). Working with adult learners. Toronto, Canada: Wall and Emerson.

Cranton, P. (1994). Understanding and promoting transformative learning. San Francisco, CA: Jossey-Bass.

Cranton, P. (1996). Professional development as transformative learning. San Francisco, CA: Jossey-Bass.

Donald, J. G. (1997). Improving the environment for leaming. San Francisco, CA: Jossey-Bass.

Gross Davis, B. (1993). Tools for teaching. San Francisco, CA: Jossey-Bass.

Edgerton, R., Hutchings, P., \& Quinlan, K. (1991). The teaching portfolio: Capturing the scholarship of teaching. Washington, DC: American Association for Higher Education.

Entwistle, N., \& Ramsden, P. (1983). Understanding student learning. London, England: Croom Helm.

Fuhrman, B., \& Grasha, T. (1983). A practical handbook for college teachers. Boston, MA: Little, Brown.

Garrison, D. R. (1997). Self-directed learning: Toward a comprehensive model. Adult Education Quarterly, 48 (1), 18-34.

Glassick, C. E., Huber, M. T., \& Maeroff, G. I. (1997). Scholarship assessed. Evaluation of the professoriate. San Francisco, CA: Jossey-Bass.

Goodyear, G. E., \& Allchin, D. (1998). Statements of teaching philosophy. In M. Kaplan \& D. Lieberman (Eds.), To improve the academy, 17, 103-122, Stillwater, OK: New Forums.

Habermas, J. (1971). Knoweledge and human interests. Boston, MA: Beacon Press.

Habermas, J. (1984). The theory of communicative action. Boston, MA: Beacon Press.

Houle, C. (1961). The inquiring mind. Madison, WI: University of Wisconsin Press.

Kelly, G. A. (1955). The psychology of personal constructs. Vol 1. A theory of personality. New York, NY: Norton.

King, P. M., \& Kitchener, K. S. (1994). Developing reflective judgment. San Francisco, CA: Jossey-Bass. 
Knapper, C. K. (1995). The origins of teaching portfolios. Journal of Excellence in College Teaching, 6(1), 45-56.

Knapper, C. K., McFarlane, B., \& Scanlon, J. (1972). Student evaluation: An aspect of teaching effectiveness. CAUT Bulletin, 21 (2), 26-34.

Kreber, C. (1998). Perfection through reflection: The teaching portfolio to evaluate and professionalize university teaching (in German). In Handreichungen zur hochschuldidaktik (section 18, pp. 1-24), Handbuch Hochschullehre. Bonn, Germany: Raabe Verlag.

Kreber, C. (1999). A course-based approach to the development of teachingscholarship: A case study. Teaching in Higher Education, 4 (3), 309-325.

Kreber, C. (Ed). (in press). Revisiting scholarship: Identifying and implementing the scholarship of teaching (tentative title). New Directions for Teaching and Learning. San Francisco, CA: Jossey-Bass.

Kreber, C. (in press). Observations, reflections, and speculations: What we have learned about the scholarship of teaching and where it might lead. In C. Kreber (Ed.), Revisiting scholarship: Identifying and implementing the scholarship of teaching (tentative title). New Directions for Teaching and Learning. San Francisco, CA: Jossey-Bass.

Kreber, C., \& Cranton, P. A. (in press). Exploring the scholarship of teaching. Journal of Higher Education, 71 .

Lawson, K. H. (1991). Philosophical foundations. In P. Jarvis \& J. M. Peters (Eds.), Adult education (pp. 282-301). San Francisco, CA: Jossey-Bass.

Matthews, R. (1996). Collaborative learning: Creating knowledge with students. In R. Menges \& M. Weimer (Eds.), Teaching on solid ground (pp. 101-124). San Francisco, CA: Jossey-Bass.

Menges, R., \& Weimer, M. (Eds.). (1996). Teaching on solid ground. San Francisco, CA: Jossey-Bass.

Mezirow, J. (1991). Transformative dimensions of adult learning. San Francisco, CA: Jossey-Bass.

Ozmon, H., \& Graver, S. (1990). Philosophical foundations of education (4th edition). Toronto, Canada: Merrill.

Pascarella, E. T., \& Terenzini, P. T. (1991). How college affects students : Findings and insights from twenty years of study. San Francisco, CA: Jossey-Bass.

Paulsen, M. B. (in press). The relation between research and the scholarship of teaching. In C. Kreber (Ed.), Revisiting scholarship: Identifying and implement- 
ing the scholarship of teaching (tentative title). New Directions for Teaching and Learning. San Francisco, CA: Jossey-Bass.

Paulsen, M. B., \& Feldman, K. A. (1995). Toward a reconceptualization of scholarship: A human action system with functional imperatives. Journal of Higher Education, 66, 615-641.

Perry, W. G. (1970). Forms of intellectual and ethical development in the college years: $A$ scheme. Troy, MO: Holt, Rinehart, \& Winston.

Rice, R. E. (1991). The new American scholar: Scholarship and the purposes of the university. Metropolitan Universities, 1, 7-18.

Rice, R. E. (1992). Toward a broader conception of scholarship: The American context. In T. G. Whiston, \& R. L. Geiger (Eds.), Research and higher education: The United States and the United Kingdom (pp. 117-129). Buckingham, England: The Society for Research into Higher Education and Open University Press.

Richlin, L. (1995). A different view on developing teaching portfolios: Ensuring safety while honouring practice. Journal of Excellence in College Teaching, 6 (1), 161-178.

Richlin, L. (Ed.). (1993). Preparing faculty for new conceptions of scholarship. New Directions for Teaching and Learning, No. 54. San Francisco, CA: Jossey-Bass.

Scott, S. M., Chovanec, D. M. \& Young, B. (1994). Philosophy-in-action in university teaching. The Canadian Joumal of Higher Education. XXIV (3), 1-25.

Shore, B. M., Foster, S. F., Knapper, C. K, Nadeau, G. G., Neill, N., \& Sim, V. $(1980,1986)$ The teaching dossier: A guide to its preparation and use. (Rev. ed.). Montreal, Canada: Canadian Association of University Teachers.

Shulman, L. S. (1998). Course anatomy: The dissection and analysis of knowledge through teaching. In P. Hutchings (Ed.), The course portfolio. Washington, DC: American Association for Higher Education.

Smith, R. A. (1995). Creating a culture of teaching through the teaching portfolio. Joumal of Excellence in College Teaching, 6(1), 75-100.

Svinicki, M. D., \& Dixon, N. (1987). The Kolb model modified for classroom activities. College Teaching, 35 (4), 141-146.

Theall, M., \& Centra, J. A. (in press). Assessing the scholarship of teaching: Valid decisions from valid evidence. In C. Kreber (Ed.), Revisiting scholarship: Identifying and implementing the scholarship of teaching (tentative title). New Directions for Teaching and Learning. San Francisco, CA: Jossey-Bass.

Weimer, M. (1987). Theories of teaching. The Teaching Professor, 1(3), 1-2. 
Contact:

Carolin Kreber

Adult and Higher Education

Department of Educational Policy Studies

7-151 Education North

University of Alberta

Edmonton, ABT6G 2G5

Canada

(780) $492-7623$

(780) 492-2024 (Fax)

Email: carolin.kreber@ualberta.ca

Carolin Kreber has been a faculty member in the Department of Educational Policy Studies at the University of Alberta since 1997. She teaches undergraduate and graduate courses on the psychology of adult learning, adult development, and instructional design. From 1993 to 1997 she worked as an educational development consultant at the Instructional Development Office at Brock University in Southern Ontario. Her present research focuses on faculty's integration of their professorial roles, the development and assessment of the scholarship of teaching, and student learning in science. 